\title{
Remarks on the Uruguay Round Negotiations
}

\author{
by Charles R. Carlisle*
}

I shall present here the Uruguay Round negotiations which aim to establish a comprehensive agreement in services, an agreement which could have a significant impact on the insurance businesses. Before 1 do that, however, I would like to describe the overall negotiations, for the services negotiations are but one part of a much larger effort.

\section{The Uruguay Round}

How large is that effort? Put simply, it is the largest trade negotiation in history, and certainly one of the most complex and ambitious economic negotiations ever undertaken.

Essentially, the GATT Uruguay Round negotiations, now in their fifth year, are attempting to deal with everything that moves, invisible as well as visible, in international commerce. They are the most serious effort yet to bring trade in two categories of goods agriculture and textiles and clothing - effectively under GATT rules. Moreover, the negotiations have moved deeply into areas of what up to now have been mainly the concern of national governments, the protection of intellectual property, investment rules and furnishing of services.

But there is more. In addition to the five subjects I have mentioned, there are ten others: GATT's traditional subjects, the reduction of tariffs and quotas; tropical products; natural resources; the revision of certain parts of the general agreement itself; amendment of the rules concerning actions to prevent import surges and measures against dumping and subsidies; dispute settlement; and the functioning of the GATT.

We cannot deal with these subjects piece-meal. To achieve success we must have a package, a package that essentially embraces all 15 subjects, a package that embraces a very large number of economic and political trade-offs. For we must deal with a fundamental reality: no government is ready to make domestically difficult concessions until it knows what it will receive in return.

Let me put the matter another way. If we are unable to reach agreement in textiles and clothing, to mention one example, or agriculture, to mention another, then we almost certainly will not be able to conclude the negotiations in services. It is just that simple - and just that important.

* Deputy Director-General of The General Agreement on Tariffs and Trade (GATT), presented before the eighteenth General Assembly of the Geneva Association, London, 10 June 1991. 
I am sure you know that this has not becn an easy negotiation - that is quite an understatement - and that at last December's Brussels ministerial meeting we suffered a very serious setback. In late February, however, after some touch-and-go discussions, we were able to restart the round.

Since then, our meetings have been low-key and focused on technical issues. Technical because there is a great deal of useful, technical work to do - work that regrettably has not been done in over four ycars - especially in agriculture and services. And technical because - let us admit it - governments are not yet ready to make the hard political decisions that will produce the breakthroughs necessary to success.

No new deadline has been set for the Round's completion. This, I believe, is wise. We missed one deadline last December. If we were to miss another, the Uruguay Round almost certainly would be over.

That said, there is a wide spread desire to conclude the Round by the cnd of this year if at all possible. In my judgment we can achieve a successful result by year's end, but that will mean a difficult summer with some distinct progress before the August holidays, and an even more difficult autumn.

Most of all it will mean that people at the highest levels of Government - prime ministers and presidents - will have to become actively involved and make some politically courageous decisions.

\section{The services negotiations}

Having given some idea of the overall scope and difficulty of the Uruguay Round negotiations, I turn now to the subject that probably interests the insurance industry most, the services negotiations.

Here again the goal is ambitious - to conclude a comprehensive agreement, consisting of a set of rules providing for the progressive liberalization of world trade in services, plus a broad package of specific liberalization commitments.

Needless to say, there is a great deal of work to do, but the shape of the final agreement can be clearly seen now. It will have three major elements.

The first is the text of the agreement itself. It basically aims at achieving progressively higher levels of liberalization of trade in services, and at providing more stability and predictability in this trade. It also would requirc that all relevant laws and regulations be published and otherwise made known to intercsted persons and companies.

The second major element comprises the "sectoral annexes", which will form an integral part of the agreement. Therc are now eight scctoral annexes in various stages of completion covering, for example, financial services, maritime transport, labor mobility and telecommunications. Their aim is to interprct or, in somc cases, qualify the application of provisions of the main text to take account of the particular charactcristics of specific sectors. And since insurance is in the busincss of providing services I do not have to insist on the fact that each servicc sector has its own particular charactcristics of an economic or regulatory nature.

The third element comprises commitments to liberalize. These commitments will be sccured through a process of negotiations among individual countries, starting now. In 
essence, governments will exchange commitments to grant market access and national treatment to services and service providers from foreign countries.

Let me elaborate on each of these three elements:

On the text of the agreement itself, negotiations have been continuous and intensive for four years. The result is a draft agreement of 35 articles covering a number of GATTlike principles. The main ones are:

- Non-discrimination between countries: this means that all signatories to the agreement must be given the most favourable trading terms available to other nations.

- National treatment: foreign and domestic services companies must be treated equally. Signatories, however, will be able to negotiate the exclusion of those specific services which they do not want subjected to this obligation.

- Transparency: this bit of GATT jargon simply means that rules, regulations and procedures which affect trade in services must be made public. Given the prevalence and complexity of insurance regulations, as well as the scope of administrative discretion in applying them, transparency will be particularly important to the companies.

- Progressive lowering of trade barriers: the agreement will be a long-term undertaking, and there will be appropriate flexibility for countries progressively to lower barriers to trade. For example, countries which until recently had centrally-planned economies may start from a position in which insurance institutions have been shielded from competition for many years. They may, therefore, need longer than traditionally marketoriented countries to adapt their insurance systems to a change in competitive conditions.

Turning to the sectoral annexes, at the time of the Brussels meeting, draft annexes were in place for the transport sectors (air, maritime and land), the audiovisual sector and telecommunications services. While governments agreed on the need for a financial services annex (which would cover insurance), they were unable to agree on even the nature and content of a draft annex.

The financial services annex sent to Brussels was literally a blank sheet of paper with just a footnote acknowledging the need for an annex. The main points of agreement and disagreement, however, were well-known.

Governments have agreed that the financial services sector has its own characteristics that need to be taken into account. The recognition of prudential standards, for example, is one of the things that needs to be negotiated. There is also agreement that all insurance and insurance-related services should be covered: direct insurance (life and non-life); reinsurance; insurance intermediation such as brokerage; and auxiliary services such as actuarial and risk assessment services.

The basic points of contention remain, first, whether the annex should establish different liberalization commitments for different groups of countries and, second, whether there should be a higher level of liberalization in the financial services sector than in other services sectors.

As you might suspect, important political decisions will be required to complete the work on the financial services annex as well as on other sectoral annexes. 
Turning to the third element, the liberalization commitments, it is recognized that the agreement and sectoral annexes would have much less value in the absence of specific commitments by many governments to liberalize services trade. Even before the Brussels ministerial meeting, governments began to submit initial offers guaranteeing market access and national treatment, and this process has been steadily intensified this past winter and spring.

At present, countries accounting for most of the world's trade in services have come forward with specific offers to liberalize trade across a range of sectors including insurance. Many smaller countries are in the process of preparing their offers. Bilateral negotiations are now underway to clarify and improve these offers and, at a later stage, to turn the offers into firm commitments. Eventually, the commitments would be inscribed in individual schedules and would enter into force when the agreement does.

Although I believe that it is within our power to negotiate a services agreement by the end of this year, I do not want you to think that we have an easy task ahead of US. There are major negotiating problems that still have to be resolved. Let me give you just two examples:

- The central principle of non-discrimination or most favoured-nation treatment, what the Geneva negotiators call MFN, raises political problems for some countries if applied to certain sectors. For example, the United States argues that its telecommunications market is open but that if it (the United States) commits to keeping that market open to all foreign telecommunications suppliers, the United States itself will lack leverage in opening closed foreign markets. In the case of television films, some European Community member states claim that for cultural reasons they need to impose discriminatory restrictions of foreign TV films.

- Another serious problem is the extent to which services liberalization will include the temporary movement of personnel who provide services. Should liberalization commitments include only top managers, executives and key specialists or should they also cover lower level persons and persons with lesser skills? This problem touches of course on extremely sensitive policies relating to immigration, visas and work permits.

\section{Will the Round succeed?}

I am coming to the end of my rcmarks and, of course, you want to know whether I think wc shall be successful in the months ahead.

I can recall that this time a year ago I was pessimistic about the prospects for Brussels. Unfortunately, I was right. Although I remain concerned about the number and seriousness of the problems that we confront and about the very few months that we have to resolve them, my mood has turned to one of ever-so-guarded optimism.

In agriculture, probably our most difficult subject, one secs small signs that the positions of the European Community and Japan are perhaps softening. At the same time, the positions of the United States and the "Cairns Group" of cfficient agricultural producers seem also to be more accommodating.

In services, perhaps our next most difficult subject, I have just come from two weeks of mectings. Nothing was resolved but I was struck by the friendly, problem solving 
attitude displayed by the negotiators. And it is clear that developing countries, which originally resisted even putting services on the Uruguay Round agenda, are actively and constructively negotiating.

In other subjects we have already come a long way. Many persons in Geneva believe, for example, that two weeks of hard work could conclude the negotiations in intellectual property and textiles and clothing.

Meanwhile, a process that began in the 1980s gathers increasing force as country after country in the developing world and in Central and Eastern Europe bring down trade barriers and open up their economies. This process, in some ways independent of the Uruguay Round negotiations, nonetheless is supportive of the GATT and of the Round. And it leads me to conclude that the GATT is swimming with the tide of history.

All of these things said, I do not want to leave with the impression that we have a sure thing. The Round can fail, and if it is not to fail, political leaders at the very pinnacles of government, especially in the United States, Western Europe and Japan, must confront powerful lobbies and, as I said before, make politically courageous decisions.

As we go through the very difficult next six months we shall need the help of outwardlooking, confident business people. I hope that the insurance industry, which would be the user and beneficiary of a strengthened multilateral trading system, will exert its own considerable influence on governments and press for the more open trading system that the world so badly needs. 